\title{
Oestrogen and benign prostatic hyperplasia: effects on stromal cell proliferation and local formation from androgen
}

\author{
Clement K M Ho ${ }^{1,3}$, Jyoti Nanda ${ }^{1}$, Karen E Chapman ${ }^{2}$ and Fouad K Habib ${ }^{1}$ \\ ${ }^{1}$ Prostate Research Group, University of Edinburgh Cancer Research Centre, Western General Hospital, 4th floor MRC Human Genetics Building, Crewe Road \\ South, Edinburgh EH4 2XU, UK \\ ${ }^{2}$ Endocrinology Unit, Room C 3.10, Centre for Cardiovascular Sciences, Queen's Medical Research Institute, 47 Little France Crescent, Edinburgh EH16 4TJ, UK \\ ${ }^{3}$ Clinical Biochemistry, Royal Infirmary of Edinburgh, University of Edinburgh, Little France Crescent, Edinburgh EH16 4SA, UK \\ (Correspondence should be addressed to F K Habib; Email: f.k.habib@ed.ac.uk)
}

\begin{abstract}
Oestrogens have been implicated as a cause of benign prostatic hyperplasia $(\mathrm{BPH})$. Previous animal studies led to the hypothesis that oestrogens can stimulate prostate growth, resulting in hyperplasia of the gland. In humans, the precise role of oestrogens in $\mathrm{BPH}$ pathogenesis is currently unclear. We investigated the direct effects of oestradiol on the proliferation of $\mathrm{BPH}$-derived prostate cells in culture. Oestradiol $\left(10^{-7}\right.$ and $\left.10^{-6} \mathrm{M}\right)$ moderately increased the proliferation of stromal cells in culture; this stimulation was antagonised by anti-oestrogen ICI 182780 , indicating an oestrogen receptor (ER)-mediated mechanism. By contrast, oestradiol had no effects on the proliferation of epithelial cells in culture. Parameters that can determine the response of stromal cells to oestrogens, including expression of the two
\end{abstract}

ER subtypes and aromatase activity, were investigated. ER $\beta$ expression in stromal cells in culture was demonstrated by immunohistochemistry and western blot analysis, and was confirmed by semi-quantitative RT-PCR showing higher expression of $\mathrm{ER} \beta$ than $\mathrm{ER} \alpha \mathrm{mRNA}$ in stromal cells. Aromatase, the enzyme that converts androgen precursors to oestrogens, was also examined. Aromatase mRNA and activity were detected in stromal, but not epithelial cells in culture, suggesting a mechanism whereby oestrogen concentrations can be regulated in the BPH stroma. Taken together, these findings support the hypothesis that oestrogens play a role in the pathogenesis of $\mathrm{BPH}$, a disease characterised predominantly by stromal overgrowth.

Journal of Endocrinology (2008) 197, 483-491

\section{Introduction}

Benign prostatic hyperplasia $(\mathrm{BPH})$ is a common urological problem in ageing men; patients usually present with symptoms of lower urinary tract obstruction (Uson et al. 1991, Verhamme et al. 2002). The precise aetiology of this condition is unknown. Two factors are generally considered essential for the development of BPH: ageing and the presence of a testis. Although androgens are believed to be important in the pathogenesis of $\mathrm{BPH}$, it is paradoxical that the disease typically manifests at a stage in life when androgen levels are declining (Gray et al. 1991, Harman et al. 2001). With advancing age, plasma androgen levels decrease gradually while oestrogen levels remain constant or decrease slightly, resulting in increasing ratios of oestrogen to androgen levels in plasma (Gray et al. 1991, Harman et al. 2001, Vermeulen et al. 2002).

Although oestrogens have long been implicated in causing $\mathrm{BPH}$, their exact role in the pathophysiology of this condition is unclear (Walsh \& Wilson 1976, Collins et al. 1994). An animal model of BPH showed that oestradiol exerted a synergistic effect with androgens in inducing glandular prostatic hyperplasia in castrated dogs (Walsh \& Wilson
1976, DeKlerk et al. 1979), whereas castrated dogs treated with oestradiol alone developed squamous prostate epithelial metaplasia (DeKlerk et al. 1979). These early studies led to the hypothesis that oestrogens might also exert a synergistic effect with androgens in inducing prostatic hyperplasia in man. In a model using prostate tissues isolated from aborted human fetuses and grown in athymic male mice, diethylstilbestrol (a synthetic oestrogen) induced squamous metaplasia of the prostate epithelium (Sugimura et al. 1988). However, none of the above models generated the histopathology of prostatic hyperplasia commonly seen in patients, which consists of a mixture of stromal and epithelial hyperplasia. Moreover, previous studies using animal models to investigate a role for oestrogens in $\mathrm{BPH}$ pathogenesis have been problematic because multiple endocrine factors including plasma androgen levels were altered in these animals. Oestrogens can exert both direct and indirect effects on the prostate. On the one hand, high levels of circulating oestrogens can indirectly cause regressive changes in the prostate, which are believed to be mediated by the inhibition of pituitary gonadotrophin secretion, leading to decreased testicular output of androgens and lowered plasma androgen levels (Jin et al. 1996). On the 
other hand, oestrogens may exert their effects directly on prostate cells, mediated by their cognate receptors expressed in the prostate, or via further metabolism to catechol or quinine intermediates (Ho 2004).

Oestrogens exert their effects on target gene expression by binding to specific intracellular oestrogen receptors (ERs) that function as hormone-inducible transcription factors. To date, two ER subtypes have been identified in humans: ER $\alpha$ (Greene et al. 1986) and ER $\beta$ (Mosselman et al. 1996). There is currently no consensus on the localisation of the two ER subtypes in human prostate tissues (Ehara et al. 1995, Bonkhoff et al. 1999, Pasquali et al. 2001b, Royuela et al. 2001, Tsurusaki et al. 2003), and their expression in BPHderived cells in primary culture is unclear.

Aromatase is a member of the cytochrome P450 family of enzymes and catalyses the conversion of C-19 androgen precursors to C-18 oestrogens (Simpson et al. 1994). Kinetic studies have demonstrated that this enzyme has high affinity for the weak androgen androstenedione and converts it to oestrone (Schweikert 1979, Stone et al. 1986). Although expression and function of aromatase in the human prostate is not entirely clear (Brodie et al. 1989, Matzkin \& Soloway 1992, Tsugaya et al. 1996, Hiramatsu et al. 1997), recent studies reported associations between aromatase polymorphisms and altered risks of prostatic hyperplasia (Azzouzi et al. 2002, Roberts et al. 2006). Expression of aromatase in oestrogen target tissues is likely to increase oestrogenic actions by the local conversion of androgens to oestrogens and may also represent a mechanism whereby the effects of oestrogens are regulated.

In this study, the hypothesis that oestrogens play a role in $\mathrm{BPH}$ pathogenesis was tested by investigating the effects of oestradiol on the proliferation of BPH-derived prostate cells in primary culture. Parameters that can influence the response of prostate cells to oestrogens were also examined; these include the expression of aromatase and ER subtypes.

\section{Materials and Methods}

\section{Prostate tissue and cell culture}

Prostate specimens were obtained from patients undergoing transurethral resection for the treatment of $\mathrm{BPH}$ with informed consent and approval of the local hospital ethics committee. Prostate tissue chips were placed in ice-cold RPMI 1640 medium supplemented with 5\% fetal calf serum (FCS, v/v), penicillin $(100 \mathrm{U} / \mathrm{ml})$ and streptomycin $(100 \mu \mathrm{g} / \mathrm{ml})$ for cell separation and culture. Prostate stromal and epithelial cells were isolated from $\mathrm{BPH}$ tissues and cultured as described previously (Tsugaya et al. 1996, Bayne et al. 1998). Stromal and epithelial cells were maintained in fibroblast growth medium (FGM) and epithelial cell growth medium (EGM) respectively. FGM was prepared by supplementing RPMI 1640 medium with 10\% FCS, 2 mM L-glutamine, 100 units $/ \mathrm{ml}$ penicillin and $100 \mu \mathrm{g} / \mathrm{ml}$ streptomycin. Each litre of EGM consisted of $11 \mathrm{~g}$ WAJC 404 medium powder, $6.7 \mathrm{~g}$ HEPES, $1.2 \mathrm{~g}$ sodium hydrogen carbonate, $0.5 \mathrm{mg}$ zinc stabilised insulin, $20 \mu \mathrm{g}$ cholera toxin, $392 \mu \mathrm{g}$ dexamethasone, $10 \mu \mathrm{g}$ epidermal growth factor, $0.5 \%$ FCS, 100000 units penicillin and $100 \mathrm{mg}$ streptomycin. Stromal and epithelial cell identities were established by phase contrast microscopy and immunocytochemical staining as described in previous reports (Tsugaya et al. 1996, Bayne et al. 1998). MCF-7 human mammary adenocarcinoma cells were obtained from ATCC (Teddington, UK) and maintained in minimal essential medium supplemented with 5\% FCS. All cell culture reagents were purchased from Life Technologies.

\section{Immunocytochemical localisation of ER subtypes}

$\mathrm{ER} \alpha$ antibody used is a mouse monoclonal antibody raised against N-terminal amino acids $2-185$ of human ER $\alpha$ (Santa Cruz Biotechnology, Santa Cruz, CA, USA). This region of $\mathrm{ER} \alpha$ corresponds mainly to the A/B functional domain of the receptor and shares little homology with $\operatorname{ER} \beta$ (Katzenellenbogen et al. 2000). ER $\beta$ antibody is a mouse monoclonal antibody against the C-terminal amino acids CSPAEDSKSKEGSQNPQSQ, specific for the ER $\beta 1$ protein (Serotec, Oxford, UK) (Moore et al. 1998, Saunders et al. 2000). Immunostaining of prostate cells in primary culture derived from six BPH patients was performed as described previously (Tsugaya et al. 1996). In brief, the cells were fixed with $1 \%$ formaldehyde in PBS, followed by treatment with $5 \%$ acetic acid in ethanol for antigen retrieval. Antibody dilutions used were 1:100 and 1:20 for ER $\alpha$ and ER $\beta$ respectively. MCF-7 cells, previously reported to express both ER $\alpha$ and ER $\beta$ (Boyan et al. 2003), were used as a positive control. Primary antibody was omitted in negative controls. Secondary antibody used was a biotinylated goat anti-mouse antibody (Autogen Bioclear, Calne, UK) and colour development was achieved using diaminobenzidine as chromogen (Vectastain ABC System; Vector Laboratories, Peterborough, UK).

\section{Western blot analyses}

Western blot analyses were carried out as described previously (Habib et al. 2005). In brief, MCF-7 and prostate stromal and epithelial cells were washed with PBS and lysed in loading buffer $(100 \mu \mathrm{M}$ Tris- $\mathrm{HCl}(\mathrm{pH} 6 \cdot 8), 200 \mu \mathrm{M}$ dithiothreitol, $4 \%$ SDS, $0 \cdot 4 \%$ bromophenol blue and $20 \%$ glycerol). Protein lysates (60 $\mu$ l containing $50 \mu \mathrm{g}$ protein) were electrophoresed on $8 \%$ SDS polyacrylamide gels. The gels were then electroblotted onto nitrocellulose and probed sequentially with either the ER $\alpha$ antibody used in immunohistochemistry (diluted 1:100) or a rabbit polyclonal antibody raised against amino acids 1-150 of human ER $\beta$ (diluted 1:200; Santa Cruz Biotechnology), and a monoclonal mouse anti-human actin antibody (diluted 1:200; Dako, Ely, UK). Chemiluminescence detection of antibody binding was carried out using the ECL system (Amersham). 


\section{Cell proliferation experiments}

Prostate cell proliferation in primary culture was determined using the MTS [3-(4,5-dimethylthiazol-2-yl)-5-(3-carboxymethoxyphenyl)-2-(4-sulphophenyl)-2H-tetrazolium] assay, according to the manufacturer's protocol (Promega). MTS tetrazolium compound is bioreduced by mitochondrial dehydrogenase activity in viable cells to a coloured formazan product that is soluble in tissue culture medium. This assay provides a colorimetric method for determining the number of viable cells in culture and has the advantage that nonviable cells do not form a coloured product (Maghni et al. 1999). To determine the linear range of the assay, epithelial and stromal cells were plated in triplicate at a density of $10^{3}-10^{4}$ cells per well in 96-well plates. The MTS assay was performed $4 \mathrm{~h}$ after seeding, when the cells had attached to the bottom of wells. Absorbance at $490 \mathrm{~nm}$ of $100 \mu \mathrm{l}$ MTS solution in 96-well plates was measured using a Microplate reader (Bio-Rad Laboratories) and was found in preliminary experiments to be proportional to the number of epithelial and stromal cells determined using a haemocytometer and seeded onto each well up to $\sim 8 \times 10^{3}$ cells/well (data not shown).

To investigate the effects of oestradiol (Sigma) and antioestrogen ICI 182780 (Faslodex; Tochris, Bristol, UK), epithelial cells (3000 cells/well, 6 wells per treatment/control group) were treated with physiological to pharmacological concentrations of oestradiol $\left(10^{-9}-10^{-5} \mathrm{M}\right)$ and viable cell numbers were determined by the MTS assay. Similarly, stromal cells (1800 cells/well) in FGM supplemented with either 2\% or 10\% dextran-coated charcoal-stripped FCS (DCC-FCS) were treated with various concentrations of oestradiol, with or without ICI 182780 . ICI 182780 is an oestrogen antagonist that competitively inhibits oestradiol binding to ERs and exhibits no agonist actions in vivo or in vitro (MacGregor \& Jordan 1998). Three wells per plate containing no cells served as blanks. Culture medium with or without steroids was changed every $24 \mathrm{~h}$ and contained no phenol red because of previously reported oestrogenic effect of this compound (Berthois et al. 1986). Following 2-6 days incubation at $37^{\circ} \mathrm{C}$, culture medium was carefully aspirated and viable cell numbers determined using the MTS assay as described above.

\section{Detection of ER and aromatase gene expression}

Total RNA was extracted from prostate stromal and epithelial cells derived from eight BPH patients using the TRI RNA isolation reagent (Sigma), according to the manufacturer's protocol. For RT-PCR, $2 \mu \mathrm{g}$ total RNA was reverse transcribed with $15 \mathrm{U}$ avian myeloblastosis virus reverse transcriptase in a $20 \mu \mathrm{l}$ reaction mix containing $5 \mathrm{mM}$ $\mathrm{MgCl}_{2}, 1 \mathrm{mM}$ dNTPs, $20 \mathrm{U}$ RNasin and $0.5 \mu \mathrm{g}$ oligo(dT) ${ }_{15}$ primer at $42{ }^{\circ} \mathrm{C}$ for $60 \mathrm{~min}$. Hundred microlitres of water were then added and the RT reactions from four patients were further diluted 1:10 and 1:100 with water. Ten microlitres of the diluted RT reaction mix were used in a $50 \mu \mathrm{l}$ PCR containing 1.25 U Taq DNA polymerase (Promega), $0 \cdot 4 \mu \mathrm{M}$ each of forward and reverse primers, $2 \mathrm{mM} \mathrm{MgCl}_{2}$ and $200 \mu \mathrm{M}$ dNTPs. PCR was carried out for 40 cycles (denaturing at $94{ }^{\circ} \mathrm{C}$ for $1 \mathrm{~min}$, annealing at $56^{\circ} \mathrm{C}$ for $1 \mathrm{~min}$ and extension at $72^{\circ} \mathrm{C}$ for $1 \mathrm{~min}$, followed by a final extension step of $10 \mathrm{~min}$ at $72{ }^{\circ} \mathrm{C}$ ). All RT-PCR reagents were obtained from Promega. Oligonucleotide primers (Eurogentec, Southampton, UK) corresponding to exon 2 and complementary to exon 3 of the aromatase gene were $5^{\prime}$-CCTCTGAGGTCAAGGAACAC- $3^{\prime}$ and $5^{\prime}$-CAGAGATCCAGACTCGCATG-3' respectively. PCR primers used for ER subtypes were as follows: ER $\alpha, 5^{\prime}$-TACTGCATCAGATCCAAGGG$3^{\prime}$ and $5^{\prime}$-ATCAATGGTGCACTGGTTGG-3'; ER $\beta$, $5^{\prime}$-GTTGCGCCAGCCCTGTTAC- $3^{\prime}$ and $5^{\prime}$-CTCGTCGGCACTTCTCTGTCTC- $3^{\prime}$. Negative controls were carried out for each pair of primers in which cDNA was omitted from the PCR or reverse transcriptase was omitted from the reverse transcription reaction. PCR products were size fractionated on a $1.5 \%$ agarose gel and visualised by ethidium bromide staining under u.v. illumination. The authenticity of the PCR products was confirmed by restriction digestion using AvaII (aromatase), PvuII (ER $\alpha)$ or Hinfl (ER $\beta)$.

\section{Metabolism of androstenedione by stromal cells}

On day 1 of each steroid metabolism experiment, stromal cells (passage 2 or 3) in FGM were seeded onto 6-well plates at a density of $3 \times 10^{5}$ cells/well. The medium was replaced with phenol red-free RPMI medium supplemented with $10 \%$ DCC-FCS the following day. Twenty-four hours later, the cells were incubated with $2 \mathrm{ml}$ of the same medium containing $20 \mathrm{nM}\left[{ }^{3} \mathrm{H}\right]$ androstenedione (S.A. $100 \mathrm{Ci} / \mathrm{mmol}$, Amersham Life Science) with or without aromatase inhibitor letrozole (10 or $100 \mathrm{nM}$ ). Letrozole (up to $100 \mathrm{nM}$ ) did not alter the growth of stromal cells maintained for up to 4 days. Preliminary experiments demonstrated that conversion of androstenedione to oestrone and testosterone was linear within $24 \mathrm{~h}$. No oestradiol formation was detectable within this incubation period. When testosterone was used as a substrate, the vast majority was rapidly metabolised to androstenedione in stromal cells due to high $17 \beta$-hydroxysteroid dehydrogenase activity, with no oestradiol detected (data not shown). After incubation at $37^{\circ} \mathrm{C}$, the culture medium was collected and ${ }^{14} \mathrm{C}$-labelled steroids $(50 \cdot 3-$ $53.3 \mathrm{mCi} / \mathrm{mmol}$; NEN Life Science Products, Hounslow, $\mathrm{UK}$ ) added for determination of recovery. Recovery of steroids was more than $75 \%$. Steroids were extracted with 5 vol ethyl acetate and dried at $45^{\circ} \mathrm{C}$ under a nitrogen gas stream. The cells were harvested in lysis buffer $(25 \mathrm{mM}$ Tris phosphate $(\mathrm{pH}$ 7.8), $2 \mathrm{mM}$ DTT, $1 \%$ Triton X-100 and 10\% glycerol) for protein assay (Bio-Rad Laboratories). Thin layer chromatography (TLC) was employed to separate the steroid metabolites. For the first TLC run, the residue was reconstituted in $60 \mu \mathrm{l}$ ethanol:ethyl acetate $(50: 50, \mathrm{v} / \mathrm{v})$ and developed in dichloromethane:diethyl ether $(9: 1, \mathrm{v} / \mathrm{v})$ on polysilica acid gel TLC plates impregnated with glass fibre (Gelman Sciences, Ann Arbor, MI, USA), in parallel to steroid standards. To further 
separate steroid metabolites from one another, areas of TLC plate corresponding to oestrone and $5 \alpha$-androstenedione were scraped off, eluted with ethyl acetate, dried and reconstituted as above. The second TLC run consisted of a mobile phase of benzene:ethanol (40:1, v/v). Steroids were visualised by spraying with $10 \%$ phosphomolybdic acid. Steroid metabolites were scraped off and quantified using a liquid scintillation counter as described previously (Bayne et al. 1998).

\section{Statistical analysis}

All cell proliferation experiments were carried out at least three times. Data are expressed as mean \pm s.E.M. Dunnett's test was used to compare viable cell numbers in ICI-182 780 treatment group with those of controls, and also steroid metabolites in letrozole-treated cells with those in controls. The TukeyKramer test was used to detect any difference in cell numbers between controls and oestradiol-supplemented groups, with or without ICI-182 780. Statistical analysis was performed using Prism version 4 (GraphPad Software, San Diego, CA, USA). $P<0 \cdot 05$ is considered statistically significant.

\section{Results}

\section{Effects of oestradiol on prostate cell growth}

To test the hypothesis that oestrogens play a role in the pathogenesis of $\mathrm{BPH}$, we examined the effects of oestradiol on the growth of prostate cells in culture. Proliferation of stromal cells grown in FGM supplemented with 10\% DCCFCS was not altered by $10^{-9}-10^{-5} \mathrm{M}$ oestradiol treatment up to 6 days (data not shown). However, oestradiol $\left(10^{-7}\right.$ and $\left.10^{-6} \mathrm{M}\right)$ stimulated the proliferation of stromal cells when their growth medium was supplemented with $2 \%$ DCC-FCS (the minimum concentration required to maintain cell growth; $P<0 \cdot 05$, Fig. 1A). To determine whether these effects were mediated by the ER, stromal cells were treated with oestradiol, ICI 182780 (anti-oestrogen) or both together. At concentrations ranging from $10^{-10}$ to $10^{-7} \mathrm{M}$, ICI 182780 displayed no cytotoxic effects on stromal cells maintained in FGM with 2\% DCC-FCS (data not shown). Whereas ICI $182780\left(5 \times 10^{-8} \mathrm{M}\right)$ alone had no effect on stromal cell proliferation, it antagonised the stimulation of stromal cell proliferation by oestradiol (Fig. 1B). The latter observation suggests that oestradiol increased stromal cell proliferation via an ER-mediated mechanism. By contrast, oestradiol $\left(10^{-9}-10^{-5} \mathrm{M}\right)$ treatment for 2-6 days had no effect on the proliferation of epithelial cells derived from three different $\mathrm{BPH}$ patients and maintained in EGM supplemented with 0.5\% FCS (Fig. 1C).

\section{Expression of ER subtypes in human prostate cells}

To examine whether the ER subtypes are expressed by human prostate cells in primary culture, we performed
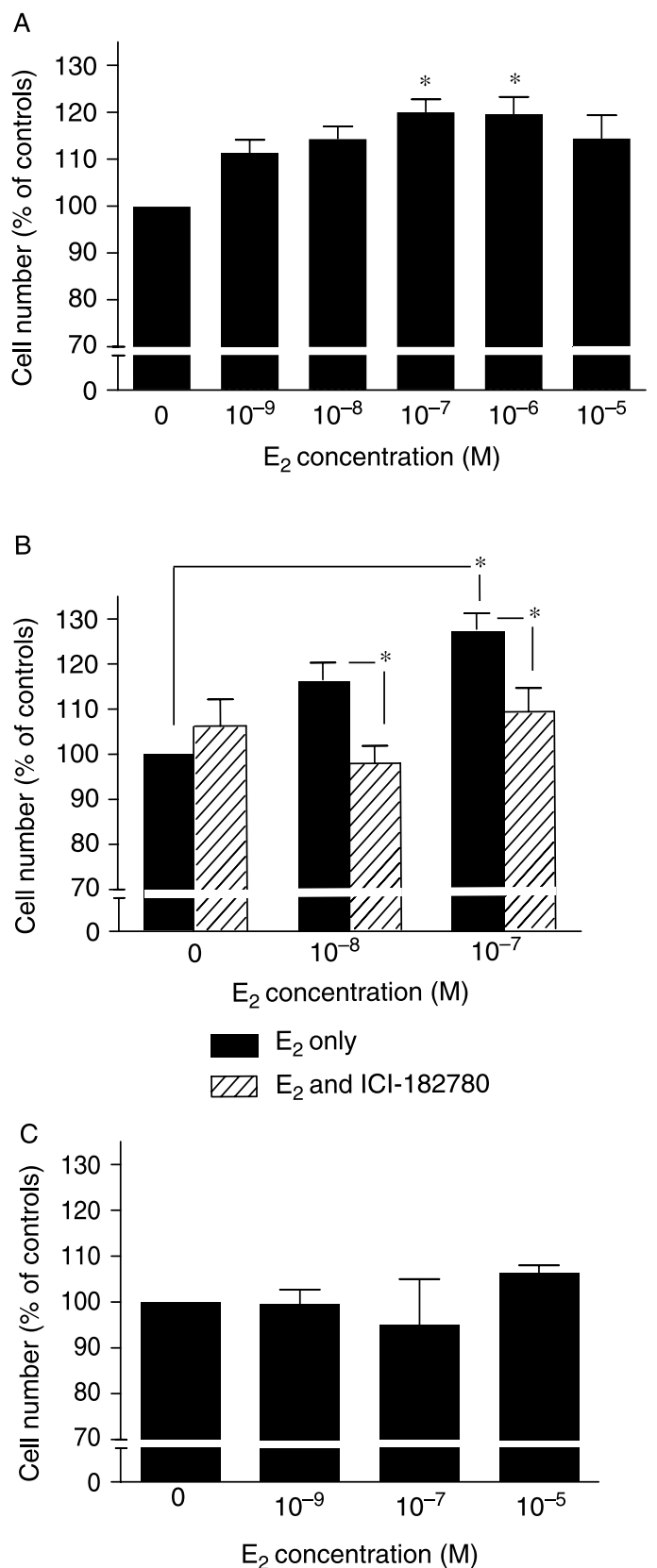

Figure 1 Effects of oestradiol on proliferation of prostate cells in primary culture. Stromal cells were plated in FGM supplemented with $2 \%$ DCC-FCS, and cell numbers were determined using the MTS assay $48 \mathrm{~h}$ after oestradiol $\left(\mathrm{E}_{2}\right)$ treatment. (A) Oestradiol $\left(10^{-7}\right.$ and $\left.10^{-6} \mathrm{M}\right)$ stimulated the proliferation of stromal cells. (B) Anti-oestrogen $\left(\mathrm{ICI} 182780,5 \times 10^{-8} \mathrm{M}\right)$ treatment abolished the stimulatory effect of $E_{2}$ on stromal cell proliferation. (C) Epithelial cells plated in EGM supplemented with $0.5 \%$ FCS were treated with $\mathrm{E}_{2}$ for $48 \mathrm{~h}$, and cell numbers were determined using the MTS assay. All results are expressed as mean \pm s.E.M. of at least three separate experiments. Cell numbers in controls are set as $100 \%$. ${ }^{*} P<0 \cdot 05$ compared with untreated control or ICI 182780 treatment group. 
immunocytochemical staining on stromal and epithelial cells derived from six BPH patients (Fig. 2). Stromal cells in culture displayed only ER $\beta$ immunostaining, which was largely localised to the nuclei (Fig. 2A). No ER $\alpha$ immunoreactivity
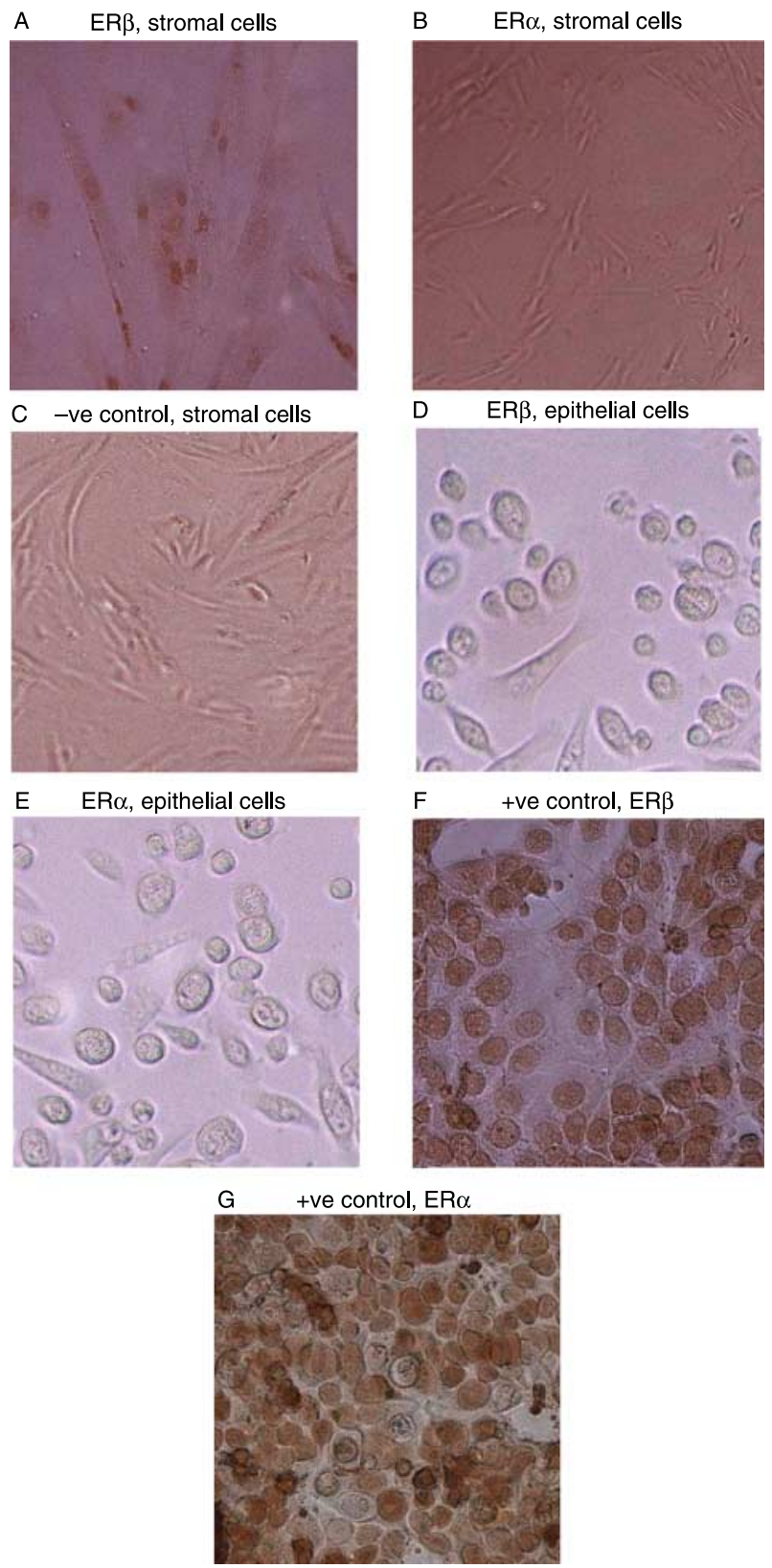

Figure 2 Immunocytochemical detection of ER subtypes in prostate cells in culture. $E R \beta$, but not $E R \alpha$, was detected in prostate stromal cells in primary culture by immunocytochemical staining. (A) Strong staining of ER $\beta$ was present in the nuclei of stromal cells, whereas (B) ER $\alpha$ immunostaining was not detectable. (C) Primary antibody was omitted from control cells. (D) ER $\beta$ and (E) ER $\alpha$ immunostaining was not detected in prostate epithelial cells. MCF-7 cells were used as positive controls for both (F) ER $\beta$ and (G) ER $\alpha(400 \times)$. was detectable in stromal cells in culture (Fig. 2B). No staining was detected in stromal cells when the primary antibody was omitted (Fig. 2C). In comparison, ER $\beta$ and ER $\alpha$ immunoreactivity was not detected in epithelial cells in culture (Fig. 2D and E). MCF-7 cells that express both ER isoforms (Boyan et al. 2003) were used as positive controls and showed strong staining with both ER $\beta$ and ER $\alpha$ antisera (Fig. 2F and G).

The expression of the ER subtypes in prostate cells was further examined by western analyses. Stromal, but not epithelial, cells from three BPH patients expressed ER $\beta$ protein detectable by western blotting (Fig. 3A). In contrast to the above immunocytochemical findings, protein lysates prepared from stromal cells displayed weak ER $\alpha$ immunoreactivity by western analysis compared with MCF-7 cells, whereas $\mathrm{ER} \alpha$ was not detected in protein lysates from epithelial cells (Fig. 3B).

Using RT-PCR, mRNA expression of both ER $\beta$ and ER $\alpha$ was detected in prostate stromal cells in culture (passages 2-5) from eight BPH patients. To investigate the expression levels of the two ER subtypes in stromal cells, semi-quantitative RT-PCR was performed in four RNA samples. ER $\beta$ RT-PCR product was detected in the undiluted RT reactions and 10-fold diluted RT reactions, but was not detected in the 100-fold diluted RT reactions (Fig. 4A). By contrast, ER $\alpha$ RT-PCR product was only detectable in undiluted RT reactions (Fig. 4B), suggesting that levels of mRNA encoding $\mathrm{ER} \alpha$ were lower than $\mathrm{ER} \beta$ mRNA in these cells.

\section{Aromatase expression and activity in prostate cells}

Aromatase mRNA was detected by RT-PCR in all stromal cell samples (passages 2-5) derived from eight $\mathrm{BPH}$ patients, using undiluted RT reactions (Fig. 4C). By contrast, no

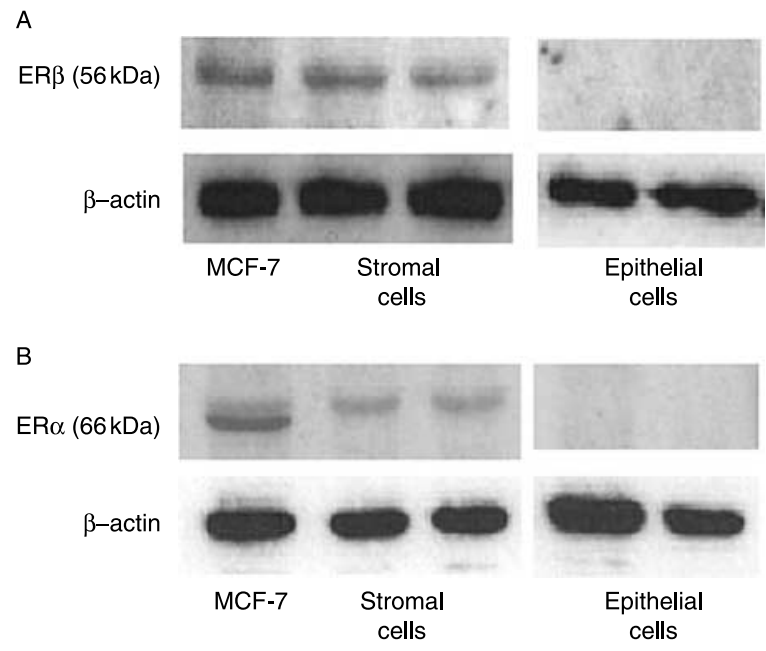

Figure 3 (A) ER $\beta$ was identified by western blot analysis of protein lysates from stromal, but not epithelial, cells. (B) Weak immunoreactivity was detected in stromal, but not epithelial, cell lysates using anti-ER $\alpha$ antisera. MCF-7 cells were used as positive controls for both $E R \beta$ and $E R \alpha$. 
Passage number

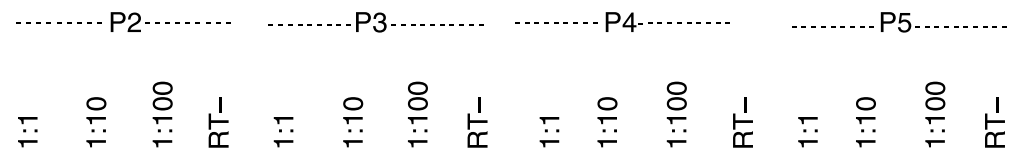

A $\mathrm{ER} \beta$

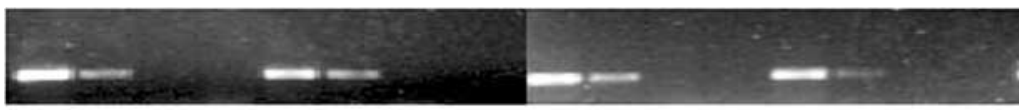

B

$\mathrm{ER} \alpha$

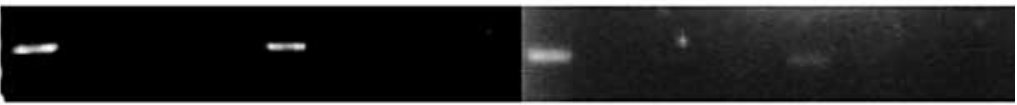

C

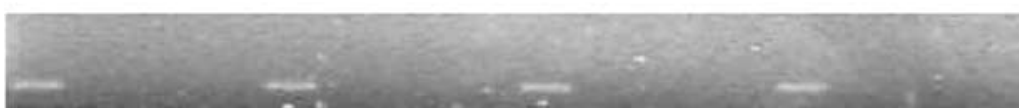

Aromatase

Figure 4 Expression of ER subtypes and aromatase mRNA in stromal cells in culture. Total RNA was prepared from stromal cells (passages 2-5) derived from three BPH patients. The same amount of RNA from each sample underwent RT under identical conditions. PCRs (40 cycles) were carried out on undiluted (1:1), 10-fold (1:10) and 100-fold (1:100) diluted RT reactions. Results shown are from one patient's stromal cells and representative of all BPH patients examined. RT - , negative control in which reverse transcriptase was omitted.
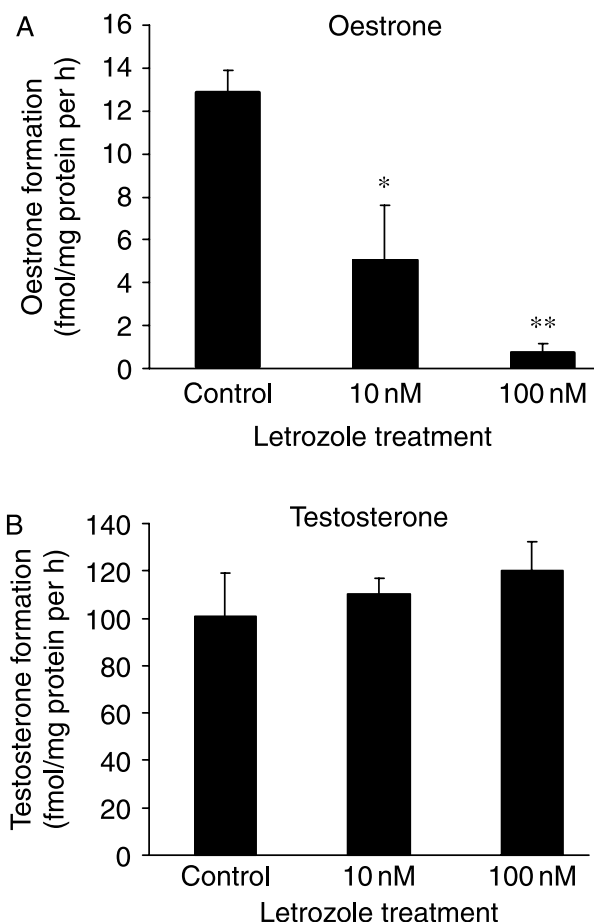

Figure 5 Metabolism of androstenedione to oestrone and testosterone in prostate stromal cells in primary culture and the effects of letrozole (aromatase inhibitor). Stromal cells were incubated with $20 \mathrm{nM}$ androstenedione for $24 \mathrm{~h}$, with or without letrozole, before culture medium was collected and steroid metabolites analysed. Values are mean of triplicates \pm S.E.M. ${ }^{*} P<0 \cdot 05$ and ${ }^{* *} P<0 \cdot 01$ compared with controls. aromatase mRNA was detectable in epithelial cell RNA derived from any of the patients (data not shown). These observations suggest a differential distribution of aromatase in the two prostate cell compartments.

Given that expression of aromatase mRNA was restricted to stromal cells, we examined its enzyme activity in cell culture. The rate of oestrone formation from androstenedione in stromal cells was $13 \pm 1 \mathrm{fmol} / \mathrm{mg}$ protein per $\mathrm{h}$ (mean \pm S.E.M). The aromatase inhibitor letrozole decreased androstenedione conversion to oestrone in a dose-dependant manner (Fig. 5A) but had no effect on testosterone formation (Fig. 5B), demonstrating that oestrone formation in stromal cells was due to aromatase activity.

\section{Discussion}

The present study shows that the prostate stroma represents a target for oestrogen action. Stromal cells not only express the ER but, by the controlled expression of aromatase, an enzyme that converts androgen precursors to oestrogens, also regulate the response to oestrogen action.

Oestradiol stimulated the proliferation of stromal, but not epithelial, cells in culture. Two previous studies have examined the effect of oestradiol on the proliferation of BPH-derived stromal cells in culture. In one study, oestradiol $\left(10^{-11}\right.$ $\left.10^{-7} \mathrm{M}\right)$ had no effect on prostate fibroblast proliferation in serum-free medium or when supplemented with 1\% FCS (Levine et al. 1992). In another study, oestradiol increased fibroblast proliferation in the medium containing $0.5 \%$ FCS; this stimulatory effect was dose dependent, with maximal stimulation at $10^{-9} \mathrm{M}$ oestradiol, and was antagonised by the anti-oestrogen, tamoxifen (Collins et al. 1994). A recent study 
reported that $5 \times 10^{-12} \mathrm{M}$ oestradiol stimulated proliferation of normal prostate stromal cells maintained in the medium containing insulin and 5\% FCS. It is likely that growth factors present in FCS or culture medium could have determined the response of stromal cells to oestradiol stimulation in these previous studies. Indeed, our data show a cell proliferation response to oestradiol when stromal cells were supplemented with $2 \%$, but not $10 \%$, DCC-FCS, suggesting that the stimulatory effect of oestradiol on stromal cell proliferation may be masked by the potent mitogenic effect of high serum concentrations in the culture medium. In comparison, oestradiol had no effect on the proliferation of epithelial cells in our study. Recently, King et al. (2006) also showed that increasing ratios of oestradiol to dihydrotestosterone levels stimulated normal human prostate stromal, but not epithelial, cell growth in culture. Together, these findings indicate that oestrogens preferentially increase the proliferation of prostate stromal cells via an ER-mediated mechanism. The differential effects of oestrogens on the two main prostate cell types in vitro are in concordance with a previous in vivo study, which showed that oestradiol treatment increased the volume of the prostate stromal compartment but decreased that of the epithelial compartment in male rats that had been castrated and supplemented with testosterone (Daehlin et al. 1987).

In this study, we demonstrated aromatase activity ( $13 \mathrm{fmol} / \mathrm{mg}$ protein per $\mathrm{h}$ ) in stromal cells comparable with activities previously reported in tissue homogenates prepared from normal and BPH tissues (Stone et al. 1986) and in cultured fibroblasts derived from BPH (Schweikert 1979). Moreover, aromatase mRNA was restricted to stromal cells and was not expressed in epithelial cells. The latter observation confirms findings from previous immunohistochemical studies, in which aromatase staining was localised to the stroma of normal and BPH prostate tissues (Matzkin \& Soloway 1992, Hiramatsu et al. 1997). Given the higher oestrogen concentrations in BPH stroma than that in epithelium reported by Kozak et al. (1982), the differential distribution of aromatase between the stromal and epithelial compartments may represent a mechanism whereby $\mathrm{BPH}$ stromal cells regulate cell proliferation by providing an oestrogenic microenvironment through the aromatisation of androgen precursors to oestrogens. The latter notion is supported by a recent study designed to examine the importance of oestrogens locally synthesised in the prostate stroma; prostate stromal tissues derived from aromatase knockout mice, but not those from normal animals, induced hyperplasia of normal prostate epithelium derived from wildtype newborn mice when the recombinant tissues were grafted into immunodeficient male hosts (McPherson et al. 2007). Taken together, the above findings suggest a role for prostate stromal aromatase in regulating the proliferation of both stromal and epithelial cells.

Data from our immunocytochemical, western blotting and semi-quantitative RT-PCR experiments indicate higher expression levels of $E R \beta$ than ER $\alpha$ in stromal cells in culture. Both immunocytochemistry and western analysis demonstrated the presence of ER $\beta$ protein in stromal cells in culture and RT-PCR confirmed the presence of the encoding mRNA. By contrast, weak ER $\alpha$ immunoreactivity was detected by western analysis in stromal cell lysates, but no $\mathrm{ER} \alpha$ staining was found in stromal cells by immunocytochemistry. Although ER $\alpha$ mRNA was detected by RT-PCR in stromal cells, it was at lower levels than ER $\beta$ mRNA. The lack of ER $\alpha$ staining by immunocytochemistry in stromal cells was probably because of the low level of protein expression. To our knowledge, ER expression in human prostate stromal cells in primary culture has been reported in only one previous study; whereas mRNA encoding ER $\alpha$, but not that encoding ER $\beta$, was detected in fibroblasts isolated from normal prostate tissues, ER $\alpha$ protein expression was not examined in the fibroblasts (Pasquali et al. 2001a). These findings are in contrast to ours. To date, the distribution of the two ER subtypes in prostate cell cultures and prostate tissues remain controversial (Ehara et al. 1995, Bonkhoff et al. 1999, Lau et al. 2000, Pasquali et al. 2001a, Royuela et al. 2001, Tsurusaki et al. 2003).

In conclusion, our findings of 1) oestradiol stimulation of in vitro stromal cell proliferation and 2) the expression of ER and aromatase in stromal cells lend support to the hypothesis that oestrogens play a role in $\mathrm{BPH}$ pathogenesis. The response of prostate cell proliferation to oestrogens most likely depends on a number of factors including plasma and local levels of oestrogens and androgens, expression of aromatase and ER subtypes, and interaction between ERs and other intracellular regulators of oestrogen action.

\section{Acknowledgements}

This study was supported by an educational grant from Pierre-Fabre Medicament. We are grateful to Prof Philippa Saunders, MRC Human Reproductive Sciences Unit, for providing us the ER $\beta$ antibody during the initial stages of this study. We also thank Dr Ruth Andrew, University of Edinburgh, for advice on steroid chromatography.

\section{Disclosure}

The authors have no conflict of interest to declare.

\section{References}

Azzouzi AR, Cochand-Priollet B, Mangin P, Fournier G, Berthon P, Latil A \& Cussenot O 2002 Impact of constitutional genetic variation in androgen/oestrogen-regulating genes on age-related changes in human prostate. European Journal of Endocrinology 147 479-484.

Bayne CW, Donnelly F, Chapman K, Bollina P, Buck C \& Habib F 1998 A novel coculture model for benign prostatic hyperplasia expressing both isoforms of 5 alpha-reductase. Journal of Clinical Endocrinology and Metabolism 83 206-213. 
Berthois Y, Katzenellenbogen JA \& Katzenellenbogen BS 1986 Phenol red in tissue culture media is a weak estrogen: implications concerning the study of estrogen-responsive cells in culture. PNAS 83 2496-2500.

Bonkhoff H, Fixemer T, Hunsicker I \& Remberger K 1999 Estrogen receptor expression in prostate cancer and premalignant prostatic lesions. American Journal of Pathology 155 641-647.

Boyan BD, Sylvia VL, Frambach T, Lohmann CH, Dietl J, Dean DD \& Schwartz Z 2003 Estrogen-dependent rapid activation of protein kinase C in estrogen receptor-positive MCF-7 breast cancer cells and estrogen receptor-negative HCC38 cells is membrane-mediated and inhibited by tamoxifen. Endocrinology 144 1812-1824.

Brodie AM, Son C, King DA, Meyer KM \& Inkster SE 1989 Lack of evidence for aromatase in human prostatic tissues: effects of 4-hydroxyandrostenedione and other inhibitors on androgen metabolism. Cancer Research 49 6551-6555.

Collins AT, Zhiming B, Gilmore K \& Neal DE 1994 Androgen and oestrogen responsiveness of stromal cells derived from the human hyperplastic prostate: oestrogen regulation of the androgen receptor. Journal of Endocrinology 143 269-277.

Daehlin L, Bergh A \& Damber JE 1987 Direct effects of oestradiol on growth and morphology of the Dunning R3327H prostatic carcinoma. Urological Research 15 169-172.

DeKlerk DP, Coffey DS, Ewing LL, McDermott IR, Reiner WG, Robinson CH, Scott WW, Strandberg JD, Talalay P, Walsh PC et al. 1979 Comparison of spontaneous and experimentally induced canine prostatic hyperplasia. Journal of Clinical Investigation 64 842-849.

Ehara H, Koji T, Deguchi T, Yoshii A, Nakano M, Nakane PK \& Kawada Y 1995 Expression of estrogen receptor in diseased human prostate assessed by non-radioactive in situ hybridization and immunohistochemistry. Prostate $\mathbf{2 7}$ 304-313.

Gray A, Feldman HA, McKinlay JB \& Longcope C 1991 Age, disease, and changing sex hormone levels in middle-aged men: results of the Massachusetts Male Aging Study. Journal of Clinical Endocrinology and Metabolism 73 1016-1025.

Greene GL, Gilna P, Waterfield M, Baker A, Hort Y \& Shine J 1986 Sequence and expression of human estrogen receptor complementary DNA. Science 231 1150-1154.

Habib FK, Ross M, Ho CK, Lyons V \& Chapman K 2005 Serenoa repens (Permixon) inhibits the 5alpha-reductase activity of human prostate cancer cell lines without interfering with PSA expression. International Journal of Cancer 114 190-194.

Harman SM, Metter EJ, Tobin JD, Pearson J \& Blackman MR 2001 Longitudinal effects of aging on serum total and free testosterone levels in healthy men. Baltimore Longitudinal Study of Aging. Journal of Clinical Endocrinology and Metabolism 86 724-731.

Hiramatsu M, Maehara I, Ozaki M, Harada N, Orikasa S \& Sasano H 1997 Aromatase in hyperplasia and carcinoma of the human prostate. Prostate $\mathbf{3 1}$ $118-124$.

Ho SM 2004 Estrogens and anti-estrogens: key mediators of prostate carcinogenesis and new therapeutic candidates. Journal of Cellular Biochemistry 91 491-503.

Jin B, Turner L, Walters WA \& Handelsman DJ 1996 The effects of chronic high dose androgen or estrogen treatment on the human prostate [corrected]. Journal of Clinical Endocrinology and Metabolism $\mathbf{8 1}$ 4290-4295.

Katzenellenbogen BS, Montano MM, Ediger TR, Sun J, Ekena K, Lazennec G, Martini PG, McInerney EM, Delage-Mourroux R, Weis K et al. 2000 Estrogen receptors: selective ligands, partners, and distinctive pharmacology. Recent Progress in Hormone Research 55 163-193 (discussion 194-165).

King KJ, Nicholson HD \& Assinder SJ 2006 Effect of increasing ratio of estrogen: androgen on proliferation of normal human prostate stromal and epithelial cells, and the malignant cell line LNCaP. Prostate 66 105-114.

Kozak I, Bartsch W, Krieg M \& Voigt KD 1982 Nuclei of stroma: site of highest estrogen concentration in human benign prostatic hyperplasia. Prostate 3 433-438
Lau KM, LaSpina M, Long J \& Ho SM 2000 Expression of estrogen receptor (ER)-alpha and ER-beta in normal and malignant prostatic epithelial cells: regulation by methylation and involvement in growth regulation. Cancer Research 60 3175-3182.

Levine AC, Ren M, Huber GK \& Kirschenbaum A 1992 The effect of androgen, estrogen, and growth factors on the proliferation of cultured fibroblasts derived from human fetal and adult prostates. Endocrinology 130 2413-2419.

MacGregor JI \& Jordan VC 1998 Basic guide to the mechanisms of antiestrogen action. Pharmacological Reviews 50 151-196.

Maghni K, Nicolescu OM \& Martin JG 1999 Suitability of cell metabolic colorimetric assays for assessment of $\mathrm{CD} 4+\mathrm{T}$ cell proliferation: comparison to 5-bromo-2-deoxyuridine (BrdU) ELISA. Journal of Immunological Methods 223 185-194.

Matzkin H \& Soloway MS 1992 Immunohistochemical evidence of the existence and localization of aromatase in human prostatic tissues. Prostate 21 309-314

McPherson SJ, Ellem SJ, Simpson ER, Patchev V, Fritzemeier KH \& Risbridger GP 2007 Essential role for estrogen receptor beta in stromalepithelial regulation of prostatic hyperplasia. Endocrinology 148 566-574.

Moore JT, McKee DD, Slentz-Kesler K, Moore LB, Jones SA, Horne EL, Su JL, Kliewer SA, Lehmann JM \& Willson TM 1998 Cloning and characterization of human estrogen receptor beta isoforms. Biochemical and Biophysical Research Communications 247 75-78.

Mosselman S, Polman J \& Dijkema R 1996 ER $\beta$ : identification and characterization of a novel human estrogen receptor. FEBS Letters 392 49-53.

Pasquali D, Rossi V, Esposito D, Abbondanza C, Puca GA, Bellastella A \& Sinisi AA 2001a Loss of estrogen receptor beta expression in malignant human prostate cells in primary cultures and in prostate cancer tissues. Journal of Clinical Endocrinology and Metabolism 86 2051-2055.

Pasquali D, Staibano S, Prezioso D, Franco R, Esposito D, Notaro A, De Rosa G, Bellastella A \& Sinisi AA $2001 b$ Estrogen receptor beta expression in human prostate tissue. Molecular and Cellular Endocrinology 178 47-50.

Roberts RO, Bergstralh EJ, Farmer SA, Jacobson DJ, Hebbring SJ, Cunningham JM, Thibodeau SN, Lieber MM \& Jacobsen SJ 2006 Polymorphisms in genes involved in sex hormone metabolism may increase risk of benign prostatic hyperplasia. Prostate 66 392-404.

Royuela M, de Miguel MP, Bethencourt FR, Sanchez-Chapado M, Fraile B, Arenas MI \& Paniagua R 2001 Estrogen receptors alpha and beta in the normal, hyperplastic and carcinomatous human prostate. Journal of Endocrinology 168 447-454.

Saunders PT, Millar MR, Williams K, Macpherson S, Harkiss D, Anderson RA, Orr B, Groome NP, Scobie G \& Fraser HM 2000 Differential expression of estrogen receptor-alpha and -beta and androgen receptor in the ovaries of marmosets and humans. Biology of Reproduction 63 1098-1105.

Schweikert HU 1979 Conversion of androstenedione to estrone in human fibroblasts cultured from prostate, genital and nongenital skin. Hormone and Metabolic Research 11 635-640.

Simpson ER, Mahendroo MS, Means GD, Kilgore MW, Hinshelwood MM, Graham-Lorence S, Amarneh B, Ito Y, Fisher CR, Michael MD et al. 1994 Aromatase cytochrome P450, the enzyme responsible for estrogen biosynthesis. Endocrine Reviews 15 342-355.

Stone NN, Fair WR \& Fishman J 1986 Estrogen formation in human prostatic tissue from patients with and without benign prostatic hyperplasia. Prostate 9 311-318.

Sugimura Y, Cunha GR, Yonemura CU \& Kawamura J 1988 Temporal and spatial factors in diethylstilbestrol-induced squamous metaplasia of the developing human prostate. Human Pathology 19 133-139.

Tsugaya M, Habib FK, Chisholm GD, Ross M, Tozawa K, Hayashi Y, Kohri K \& Tanaka S 1996 Testosterone metabolism in primary cultures of epithelial cells and stroma from benign prostatic hyperplasia. Urological Research 24 265-271.

Tsurusaki T, Aoki D, Kanetake H, Inoue S, Muramatsu M, Hishikawa Y \& Koji T 2003 Zone-dependent expression of estrogen receptors alpha and beta in human benign prostatic hyperplasia. Journal of Clinical Endocrinology and Metabolism 88 1333-1340. 
Uson AC, Paez AB \& Uson-Jaeger J 1991 The natural history and course of untreated benign prostatic hyperplasia. European Urology 20 (Suppl 1) 22-26

Verhamme KM, Dieleman JP, Bleumink GS, van der Lei J, Sturkenboom MC, Artibani W, Begaud B, Berges R, Borkowski A, Chappel CR et al. 2002 Incidence and prevalence of lower urinary tract symptoms suggestive of benign prostatic hyperplasia in primary care-the Triumph project. European Urology 42 323-328.

Vermeulen A, Kaufman JM, Goemaere S \& van Pottelberg I 2002 Estradiol in elderly men. Aging Male 5 98-102.
Walsh PC \& Wilson JD 1976 The induction of prostatic hypertrophy in the dog with androstenediol. Journal of Clinical Investigation 57 1093-1097.

Received in final form 29 March 2008

Accepted 4 April 2008

Made available online as an Accepted Preprint 4 April 2008 